poor, nausea and vomiting were reduced by increasing the dose of the maintenance infusion during subsequent treatment to 5 and $6 \mathrm{mg} / \mathrm{kg}$, respectively. This shows that the antiemetic effect of the drug can be optimised individually.

Neither regimen produced excessive side effects. Interestingly, diarrhoea was considerably reduced in the group receiving the continuous infusion, and it may be that wide fluctuations in plasma metoclopramide concentrations result in excessive intestinal hurry with resultant diarrhoea. Extrapyramidal reactions to metoclopramide are rare in this age group.

In view of an increasing tendency towards combination antiemetic treatment for emesis induced by cytotoxic drugs and the attendant concern over potential drug interactions the optimal use of individual antiemetics is considerably important. Thus we are encouraged by the considerable improvement in antiemetic effect achieved by high dose metoclopramide given as a loading dose and maintenance infusion after the application of simple pharmacokinetic principles. Future studies need to address the problems of the route and technique of administration of antiemetics and the dosage as well as identifying new compounds and combinations. Kris et al documented the time course of nausea and vomiting after administration of cisplatin. ${ }^{2}$ They showed that nausea persisted for five days in $40 \%$ of patients and vomiting in $20 \%$, with a peak incidence at three days after administration. In our study there was no difference in the duration of nausea and vomiting between the two arms, but the peak incidence of delayed nausea at three days agrees with the study of Kris et al. ${ }^{2}$ This suggests that control of acute emesis after cisplatin does not necessarily reduce subsequent delayed emesis, and thus further improvements are required.
We thank the pharmacy department and the nursing staff in the department of clinical oncology for their help in this study. We also thank Miss M E Kerr for statistical help.

\section{References}

1 Coates A, Abraham S, Kaye SB, et al. On the receiving end-patient perception of the side-effects of ancer chemother. Eur 7 Cancer Clin Oncol 1983;19:203-8.

2 Kr KMG, Grall RA, Clark RA, al. Incidence, course and severity of delayed nausea and ( vomiting following the administration of high dose cis-platinum. I Clin Oncol 1985;3:1379-84. Gralla RJ, Litri LM, Pisko SE, et al. Anti-emetic efficacy of high dose metoclopramide randomised trial with placebo and prochlorperazine in patients with chemotherapy-induced nausea and vomiting. $N$ Engl $\mathcal{M}$ Med 1981;305:905-9.

4 Strum SB, McDermed JE, Opfell RW, Riech LP. Intravenous metoclopramide. An effective antiemetic in cancer chemotherapy. $\mathcal{F A M A ~ 1 9 8 2 ; 2 4 7 : 2 6 8 3 - 6 .}$

5 Allan SG, Cornbleet MA, Lockhart SP, Warrington PS, Leonard RCF, Smyth JF. Emesis due to cancer chemotherapy: results of a prospective, randomised, double-blind trial of varying doses of metoclopramide in the management of cis-platinum-induced vomiting. Eur $\mathrm{f}$ Cancer $\mathrm{Clin}$ Oncol 1984;20:1481-4.

6 Allan SG, Cornbleet MA, Warrington PS, Leonard RCF, Smyth JF. Dexamethasone and high dose metoclopramide effective in controlling cis-platinum-induced vomiting. $\mathrm{Br}$ Med $f$ 1984;289:878-9.

7 Meyer RB, Lewin M, Drayer DE, et al. Optimizing metoclopramide control of cis-platinuminduced emesis. Ann Intern Med 1984;100:363-5.

Taylor WB, Bateman DN. High dose metoclopramide-preliminary pharmacokinetic studies. $B r$ f Clin Pharmacol 1983;16:341-2.

9 Bateman DN, Gokal R, Dodds TRP, et al. The pharmacokinetics of single doses of metoclopramide in renal failure. Eur $\mathcal{F}$ Clin Pharmacol 1981;19:437-41.

10 Winter ME, Katcher BS, Koda-Kimble MA, eds. Basic clinical pharmacokinetics. San Francisco, Applied Therapeutics Inc, 1980:5-67.

1 Taylor WB, Proctor SJ, Bateman DN. Pharmacokinetics and efficacy of high-dose metoclopramide given by continuous infusion for the control of cytotoxic drug-induced vomiting. $\mathrm{Br} \mathcal{J}$ Clin Pharmacol 1984;18:679-84

12 McDermed JE, Cohen JL, Joseph C, Strum SB. Clinical pharmacokinetics of high dose metoclopramide in cancer patients receiving cisplatin therapy. $\mathcal{F}$ Clin Oncol 1985;3:1400-8.

Accepted 20 August 1986

\title{
Dose dependent response of symptoms, pituitary, and bone to transdermal oestrogen in postmenopausal women
}

\author{
P L SELBY, M PEACOCK
}

\begin{abstract}
The effect of the plasma oestradiol concentration on climacteric symptoms, gonadotrophin release, and bone resorption was studied in three groups of postmenopausal women given $\mathbf{0 . 0 2 5}$ $\mathrm{mg}, \mathbf{0 . 0 5} \mathrm{mg}$, or $\mathbf{0 . 1} \mathrm{mg}$ transdermal oestradiol daily. There was a dose related reduction in symptoms, plasma follicle stimulating hormone concentration, and urinary calcium and hydroxyproline excretion. The relation of the response to plasma oestradiol values was similar for each variable with an initial large reduction and little change in response to increases in the plasma oestradiol concentration above $150 \mathrm{pmol} / \mathrm{l}(41 \mathrm{pg} / \mathrm{ml})$.
\end{abstract}

Hormone replacement therapy producing an effect equivalent to higher oestradiol concentrations is likely to increase the risk of side effects without conferring any additional benefit.

MRC Mineral Metabolism Unit, The General Infirmary, Leeds LS1 3EX

P L SELBY, MA, MRCP, honorary senior registrar

M PEACOCK, MB, FRCP, acting director, honorary consultant physician

Correspondence to: Dr Peacock.

\section{Introduction}

Oestrogen replacement in postmenopausal women reduces both symptoms of the climacteric and excess bone resorption in a dose dependent manner. ${ }^{2}$ During the menstrual cycle, however, though the changes that occur in the plasma oestrogen concentration are of the same order of magnitude as those in women receiving postmenopausal hormone replacement therapy, they are not accompanied by any change in either oestrogen dependent symptoms or bone turnover. ${ }^{3}$ A possible explanation for this difference is that the response to oestrogen is near maximal at the plasma concentration present during menstruation and that only small changes in response occur with oestrogen concentrations within and above the premenopausal range.

If the response in bone to oestrogen has this relation it has implications for postmenopausal hormone replacement treatment, since the adverse effects of oestrogen treatment are dose related. ${ }^{14}$ Moreover, high doses of oestrogen have unwanted effects on bone as a result of inhibition of bone formation, which would be avoided by using the minimal dose of oestrogen to suppress resorption.

The establishment of such a dose has thus far been difficult because oestrogens are usually given by mouth. This causes hepatic "first pass" metabolism of the oestrogen, which appears in plasma as various metabolites with variable biological activity ${ }^{5}$ and increased concentrations of sex hormone binding globulin, which reduces the free hormone. ${ }^{6}$ Taken together these two phenomena make it impossible to assign any meaningful biological value 
to measured oestrogen concentrations after oral administration. Transdermal oestrogen, however, avoids both of these effects ${ }^{5}$ and the plasma oestradiol concentration is then an accurate indicator of biological activity.

Recently a means has been devised to administer drugs transdermally at a fixed rate by using a skin patch incorporating a rate limiting membrane. ${ }^{7}$ We have used this method of delivery to study the response of symptoms, gonadotrophin release, and bone resorption to varying concentrations of plasma oestrogen in postmenopausal women.

\section{Patients and methods}

We studied 26 normal postmenopausal women attending our clinic because of symptoms of the climacteric. All were postmenopausal as defined by at least six months' amenorrhoea together with raised plasma follicle stimulating hormone and low plasma oestradiol concentrations. No patient had received any hormone replacement therapy in the month before the study and none was receiving any drug known to affect calcium or bone metabolism. All patients received treatment with transdermal oestradiol from an adhesive patch with a controlled rate of release (TTS Estraderm; Ciba-Geigy, Horsham, Sussex). Patients were randomly allocated to receive one of three different sized patches delivering oestradiol at a rate of 0.025 $\mathrm{mg}, 0.05 \mathrm{mg}$, or $0.1 \mathrm{mg}$ daily. The table gives the details of patients within each group.

All patients were studied basally and after three weeks of treatment. On each occasion a clinical assessment was made to enable a symptom score to be derived and blood and urine were obtained after an overnight fast for estimation of plasma follicle stimulating hormone and oestradiol concentrations and urinary excretion of calcium, creatinine, and hydroxyproline. Urinary calcium and creatinine were measured by standard autoanalyser techniques. Urinary hydroxyproline was measured by an automated colorimetric procedure after resin catalysed hydrolysis ${ }^{8}$ Follicle stimulating hormone and oestradiol concentrations were measured by specific radioimmunoassays.

Statistical analysis within each treatment group was by paired $t$ tests where the data were normally distributed and the Wilcoxon signed rank test otherwise.

\section{Results}

Treatment with the three doses of oestradiol resulted in a progressive rise in the mean plasma oestradiol concentration at three weeks. This rose from $36(\mathrm{SE} 4) \mathrm{pmol} / \mathrm{l}(9 \cdot 7(1 \cdot 1) \mathrm{pg} / \mathrm{ml})$ to $79(18) \mathrm{pmol} / 1(21 \cdot 3(4 \cdot 9) \mathrm{pg} / \mathrm{ml})$ $(\mathrm{p}<0.05)$ with $0.025 \mathrm{mg} /$ day; from $46(16) \mathrm{pmol} / \mathrm{l}(12.4(4.3) \mathrm{pg} / \mathrm{ml})$ to 122 (27) $\mathrm{pmol} / 1(32.9(7.3) \mathrm{pg} / \mathrm{ml})(\mathrm{p}<0.01)$ with $0.05 \mathrm{mg} /$ day; and from $41(6)$ $\mathrm{pmol} / \mathrm{l}(11 \cdot 1(1 \cdot 6) \mathrm{pg} / \mathrm{ml})$ to $281(31) \mathrm{pmol} / \mathrm{l}(75.9(8 \cdot 4) \mathrm{pg} / \mathrm{ml})(\mathrm{p}<0.001)$ with $0.1 \mathrm{mg} /$ day (table).

All doses of oestrogen led to some relief of symptoms, but this was more pronounced with the two highest doses (table).

Plasma follicle stimulating hormone concentrations fell with all doses of oestrogen: from $62.5(\mathrm{SE} 3.6) \mathrm{mU} / \mathrm{ml}$ to $51.7(4.8) \mathrm{mU} / \mathrm{ml}(\mathrm{p}<0.01)$ with $0.025 \mathrm{mg}$ daily; from $53.6(7.7) \mathrm{mU} / \mathrm{ml}$ to $38.6(5.7) \mathrm{mU} / \mathrm{ml}$ (not significant) with $0.05 \mathrm{mg}$ daily; and from $58.6(3.7) \mathrm{mU} / \mathrm{ml}$ to $34.3(5 \cdot 2) \mathrm{mU} / \mathrm{ml}$ $(\mathrm{p}<0.001)$ with $0.1 \mathrm{mg}$ daily (table)

Treatment with $0.025 \mathrm{mg}$ oestradiol daily caused a fall in urinary calcium excretion from 0.24 (SE 0.04 ) (molar ratio to creatinine) to $0.18(0.04)$, but this failed to reach statistical significance. The higher doses produced significant changes: from $0.28(0.07)$ to $0.18(0.06)(\mathrm{p}<0.01)$ with $0.05 \mathrm{mg}$ daily, and from $0.28(0.05)$ to $0.15(0.02)(\mathrm{p}<0.05)$ with $0.1 \mathrm{mg}$ daily. Similar changes also occurred in urinary hydroxyproline excretion, which rose non-significantly with $0.025 \mathrm{mg}$ daily but fell from 0.014 (SE 0.003 ) (molar ratio to creatinine) to $0.012(0.002)$ (not significant) with $0.05 \mathrm{mg}$ daily and from $0.014(0.002)$ to $0.010(0.001)(\mathrm{p}<0.05)$ with $0.1 \mathrm{mg}$ daily (table).
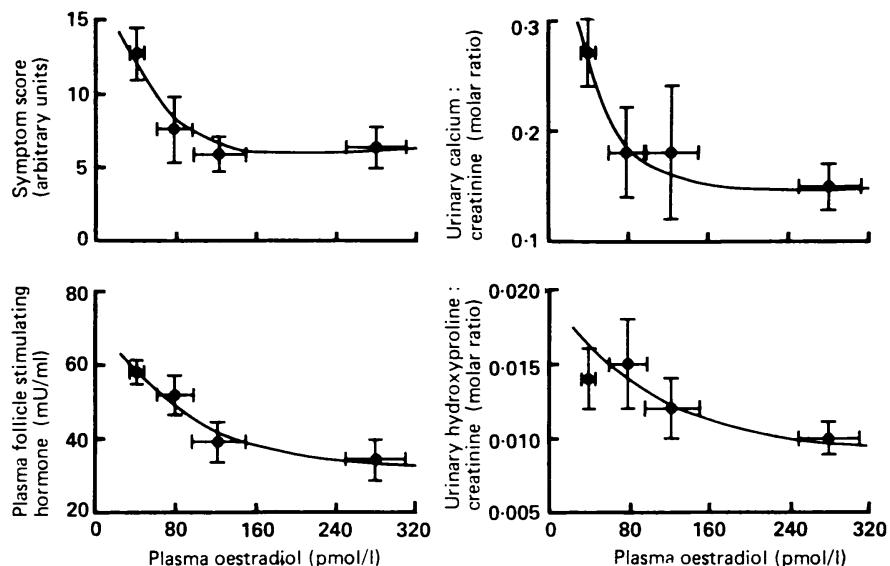

Relation between climacteric symptoms, plasma follicle stimulating hormone concentration, hydroxyproline:creatinine ratio, and calcium:creatinine ratio in urine collected after overnight fast and plasma oestradiol concentration in postmenopausal women treated with transdermal oestradiol. Data expressed as means and SE; untreated data combined for the three groups. In each case curved line is arbitrary line illustrating change in that variable with plasma oestrogen concentration.

Conversion: SI to traditional units-Oestradiol: $1 \mathrm{pmol} / \mathrm{l} \approx 0.27 \mathrm{pg} / \mathrm{ml}$.

Since there were no significant differences in untreated values of symptom score, follicle stimulating hormone concentration, and urinary calcium and hydroxyproline excretion among the three treatment groups the untreated data were combined, allowing each of the measured variables to be related to the ambient plasma oestradiol concentration as a set of dose response curves. The figure shows the result.

\section{Discussion}

This study confirms the dose dependent action of oestrogen in reducing climacteric symptoms, gonadotrophin secretion, and bone resorption in the postmenopausal state. ${ }^{12}$ Because transdermal oestradiol does not undergo "first pass" hepatic metabolism and does not alter plasma binding proteins like oral oestradiol it is possible to relate the biological responses to the measured plasma concentrations of oestradiol achieved during treatment (figure). Despite the symptom study being uncontrolled the four responses were dose dependent, the greatest response occurring in the postmenopausal range of oestradiol but becoming asymptotic above a plasma oestradiol concentration of $150 \mathrm{pmol} / 1(41 \mathrm{pg} / \mathrm{ml})$. This agrees with the observation that the changes in plasma oestradiol concentrations during the menstrual cycle, which are all above 150 $\mathrm{pmol} / \mathrm{l}$, have no measurable effect on bone turnover. ${ }^{3}$

Other workers have noted that the dose of oral oestrogen required to achieve each of its actions is different. ${ }^{1}$ This does not appear to be the case with oestradiol administered transdermally; the dose

Patient details and response to treatment. Values are means (95\% confidence limits in parentheses)

\begin{tabular}{|c|c|c|c|c|c|c|c|c|}
\hline $\begin{array}{l}\text { Oestradiol } \\
\text { dose } \\
\text { (mg/day) }\end{array}$ & $\begin{array}{c}\text { No of } \\
\text { patients }\end{array}$ & $\begin{array}{l}\text { Age at study } \\
\text { (years) } \\
\text { [range] }\end{array}$ & $\begin{array}{c}\text { Age at } \\
\text { menopause } \\
\text { (years) } \\
\text { [range] }\end{array}$ & $\begin{array}{l}\text { Plasma } \\
\text { oestradiol } \\
(\mathrm{pmol} / \mathrm{l})\end{array}$ & $\begin{array}{c}\text { Symptom } \\
\text { score } \\
\text { (arbitrary units) }\end{array}$ & $\begin{array}{l}\text { Plasma follicle stimulating } \\
\text { hormone } \\
(\mathrm{mU} / \mathrm{ml})\end{array}$ & $\begin{array}{l}\text { Urinary calcium: } \\
\text { creatinine (molar ratio) }\end{array}$ & $\begin{array}{c}\text { Urinary } \\
\text { hydroxyproline:creatinine } \\
\text { (molar ratio) }\end{array}$ \\
\hline $\begin{array}{l}\text { Nil } \\
0.025 \\
0.05 \\
0.1\end{array}$ & $\begin{array}{r}26 \\
7 \\
8 \\
11\end{array}$ & $\begin{array}{l}50[37-61] \\
49[37-57] \\
50[39-54] \\
51[37-61]\end{array}$ & $\begin{array}{l}45[33-57] \\
45[36-53] \\
46[32-53] \\
45[28-57]\end{array}$ & $\begin{array}{l}41(30-52) \\
79(35-123)^{\star} \\
122(58-186)^{\star \star} \\
281(212-350)^{\star \star \star}\end{array}$ & $\begin{array}{l}13(11-15) \\
8(3-13) \\
6(3-8)^{\star \star} \\
6(3-9)^{\star \star \star}\end{array}$ & $\begin{array}{l}58(52-64) \\
52(40-63) \\
39(23-52) \\
34(23-46)\end{array}$ & $\begin{array}{l}0 \cdot 27(0.21-0.33) \\
0 \cdot 18(0.08-0 \cdot 28) \\
0 \cdot 18(0.05-0 \cdot 31)^{\star \star} \\
0 \cdot 15(0 \cdot 11-0 \cdot 19)^{\star}\end{array}$ & $\begin{array}{l}0.014(0.010-0.018) \\
0.015(0.007-0.023) \\
0.012(0.007-0.015) \\
0.010(0.007-0.012)^{\star}\end{array}$ \\
\hline
\end{tabular}

Compared with baseline values within same treatment group: ${ }^{\star} p<0.05 ;{ }^{\star \star} p<0.01 ;{ }^{\star \star} p<0.001$.

Conversion: SI to traditional units-Oestradiol: $1 \mathrm{pmol} / \mathrm{\approx} \approx 0 \cdot 27 \mathrm{pg} / \mathrm{ml}$. 
response curves for climacteric symptoms, gonadotrophin release from the pituitary, and bone resorption are all congruent. This equivalence adds weight to our previous studies which suggested that the action of oestrogen on bone is a direct receptor mediated response similar to that underlying the reduction in follicle stimulating hormone and not an indirect action via altered concentration of the calcitropic hormones, which might be expected to produce different dose response characteristics. ${ }^{910}$

It is clear from these results that there is little to be gained from using doses of oestrogen above that which gives an effect equivalent to that produced by a plasma oestradiol concentration of $150 \mathrm{pmol} / 1$ $(41 \mathrm{pg} / \mathrm{ml})$. Indeed, any substantial increase in dose above this level is likely to increase adverse reactions without clinical benefit. Among these is the excessive suppression of bone remodelling, ${ }^{11}$ which is probably essential for the maintenance of healthy bone.

We are grateful to Dr C Chapman for the measurement of plasma follicle stimulating hormone and Dr R E Oakey for the measurement of plasma oestradiol.

\section{References}

1 Geola FL, Frumar AM, Tataryn IV, et al. Biological effects of various doses of conjugated equine estrogens in postmenopausal women. $f$ Clin Endocrinol Metab 1980;51:620-5.

2 Jones MM, Pearlman B, Marshall DH, Grilly RG, Nordin BEC. Dose-dependent response of FSH, flushes and urinary calcium to oestrogen. Maturitas 1982;4:285-90.

3 Tjellesen L, Christiansen C, Hummer L, Larsen N. Unchanged biochemical indices of bone turnover despite fluctuations in 1,25 dihydroxyvitamin $\mathrm{D}$ during the menstrual cycle. Acta Endocrinol (Copenh) 1983;102:476-80.

4 Mack TM, Pike CM, Hedeson BE, et al. Estrogens and endometrial cancer in a retirement community. N Engl f Med 1976;294:1262-7.

5 Towobola OA, Crilly RG, Oakey RE. Oestrone sulphate in plasma from postmenopausal women and the effects of oestrogen and androgen therapy. Clin Endocrinol (Oxf) 1980;13:461-71.

6 Anderson DC. Sex hormone binding globulin. Clin Endocrinol (Oxf) 1974;3:69-96.

Laufer LR, DeFazio JL, Lu JKH, et al. Estrogen replacement therapy by transdermal estradiol administration. Am f Obstet Gynecol 1983;146:533-40.

8 Hodgkinson A, Thompson T. Measurement of the fasting urinary hydroxyproline:creatinine ratio in normal adults and its variation with age and sex. $\mathcal{F}$ Clin Pathol 1982;35:807-11.

9 Selby PL, Peacock M, Barkworth SA, Brown WB, Taylor GA. Early effects of ethinyloestradiol and norethisterone treatment in postmenopausal women on bone resorption and calcium regulating hormones. Clin Sci 1985;69:265-71.

10 Selby PL, Peacock M. Ethinyl estradiol and norethindrone in the treatment of primary hyperparathyroidism in postmenopausal women. $N$ Engl f Med 1986;314:1481-5.

11 Nordin BEC, Marshall DH, Francis RM, Crilly RG. The effects of sex steroid and corticosteroid hormones on bone. I Steroid Biochem 1981;15:171-4.

(Accepted 4 September 1986)

\title{
Hepatocellular carcinoma in urban born blacks: frequency and relation to hepatitis $B$ virus infection
}

\author{
M C KEW, C KASSIANIDES, J HODKINSON, A COPPIN, A C PATERSON
}

\begin{abstract}
Chronic hepatitis B virus infection is far less common in urban born than in rural born southern African blacks, who also have a high incidence of hepatocellular carcinoma. A case-control study was carried out to determine the relative frequency of hepatocellular carcinoma and its relation to hepatitis $B$ virus infection in urban born blacks. Three hundred and ninety two black patients with hepatocellular carcinoma and matched controls seen at two city hospitals were classified by questioning as urban born or rural born. The ratio of rural born to urban born blacks among the controls was $1 \cdot 1: 1.0(207 / 185)$, whereas in the patients with cancer the ratio was 4.8:1.0 (324/68) $(\mathrm{p}<0.0001)$. Analysis of the prevalence of hepatitis $B$ markers in 62 urban born and matched rural born blacks with hepatocellular carcinoma showed no differences in the frequency of current or past hepatitis B virus infection.
\end{abstract}

It is concluded that urban born blacks are less likely than rural born blacks to develop hepatocellular carcinoma, but when they

\footnotetext{
Department of Medicine, University of Witwatersrand Medical School and Johannesburg and Baragwanath Hospitals, Johannesburg, South Africa M C KEW, MD, FRCP, professor and senior physician

C KASSIANIDES, MB, FCPSA, physician

J HODKINSON, MB, FCPSA, senior physician

Institute for Virology, Johannesburg, South Africa

A COPPIN, DMT(VIROL), technologist

South African Institute for Medical Research, Johannesburg, South Africa A C PATERSON, MB, PHD, pathologist

Correspondence to: Professor Kew
}

do the tumour is equally likely to be related to infection with hepatitis $B$ virus. The findings lend further support to an important role for chronic hepatitis B virus infection in the aetiology of hepatocellular carcinoma.

\section{Introduction}

Both chronic hepatitis B virus infection ${ }^{1-3}$ and hepatocellular carcinoma ${ }^{45}$ are common in blacks born in rural areas of southern Africa. Rates of carriage of hepatitis B virus of up to $20 \%$ have been recorded in rural blacks. ${ }^{1-3}$ The infection is almost always acquired in early childhood, predominantly as a result of horizontal transmission. ${ }^{23}$ Rural blacks develop hepatocellular carcinoma while relatively young ${ }^{67}$ and have age standardised frequency rates which may be as high as 104/100000 yearly. ${ }^{45}$ Almost all of these patients show serological markers of current or past hepatitis B virus infection. ${ }^{8}$ Nothing is yet known about either the incidence of hepatocellular carcinoma or its relation to chronic hepatitis B virus infection in blacks who are born and grow up in an urban environment. We, however, have recently shown that urban black children have a carriage rate of hepatitis B virus of only $1 \% .{ }^{9}$ If chronic infection with this virus is proved to be a main cause of hepatocellular carcinoma-and published evidence is persuasive ${ }^{10} 11$ - then the incidence of this tumour in blacks born in urban areas should be appreciably lower than that in blacks born and growing up in rural areas. We have therefore carried out a case-control study to determine the frequency of hepatocellular carcinoma in blacks born and living in an urban environment and to investigate the hepatitis B virus state of these patients.

\section{Subjects and methods}

Case-control study-The case-control study comprised 392 urban but otherwise unselected southern African blacks with histologically proved hepatocellular carcinoma and 392 matched controls. "Urban" blacks were 